\title{
On the Islamic Theory of the State
}

\author{
By HELMER RINGGREN
}

From the very beginning, Islam has devoted more interest to politics and political theory than most other religions. If it can be said with some right that Jesus was unpolitical, Muhammad was certainly not. Islam makes no distinction between religion and politics, but the two are intimately connected, and political theory has a religious and theological motivation. That implies that, in theory, it is based on the Koran and on Tradition (sunnah) in the same way as jurisprudence in general or as any other theological discipline.

Arabic literature can boast of a large number of works dealing with state theory and political questions. A general reader easily gets the impression that they are strictly theoretical and derived from the same sources as all other juristic literature: the Koran, hadith, and igm $\bar{a}^{\zeta}$. Seemingly, they carry on purely theoretical discussions without the slightest contact with real life. But on closer inspection it turns out that to a great extent these works are products of the contemporary political situation and in reality are attempting to find a theoretical motivation for existing conditions. A comparative study of some leading works on political theory will enable us to follow the course of history from the powerful caliphate under the early Abbasids down to the complete disintegration of the caliphate into a kind of purely theoretical religious authority. Erwin Rosenthal has done this in the second chapter of his book Political Thought in Medieval Islam ${ }^{1}$, and there is no reason to repeat his findings here. Instead, we shall focus our attention on the chapter on political leadership in one of the earlier classics in this field, namely al-Māwardī, Ahkāmn assulțänīyah, which is easily accessible in French translation. ${ }^{2}$

\footnotetext{
${ }^{1}$ E. Rosenthal, Political Thought in Medieval Islam, Cambridge I958.

2 al-Māwardì, Les Statuts gouvernementaux ou Règles de droit public et administratif, trad. et ann. par E. Fagnan, Algiers I 9ז 5 .
} 
Abu-1-Hasan 'Alī al-Māwardì was a prominent lawyer of the Shāfi'i school during the former half of the I Ith century (d. I058). This was a time when the power of the caliph was seriously threatened by the Buwayhid dynasty in Persia. Nicholson says in his classical Literary History of the Arabs that "his standpoint is purely theoretical". ${ }^{1}$ But in a brilliant paper "Al-Mawardi's Theory of the Caliphate", Sir Hamilton Gibb has pointed out a sentence in the author's introduction, in which he says that he has "complied with the command of one to whom it is obligatory to render obedience, in order that he may know the views of the jurists as to those ordinances which define his rights and his duties". ${ }^{2}$ That person can hardly be anyone but the reigning caliph, either al-Qādir billāh (d. Io 3 I) or his successor al-Qāim bi'amrillah. The fact is that the Buwayhids were temporarily weak at that time and that al-Māwardi often functioned as the caliph's representative in negotiations with them. It is not difficult to prove that several details in al-Māwardī's work aim at asserting the caliph's interest as against the Buwayhid princes. Here, however, we are more interested in the structure of the political system than in these details, interesting as they may be from a historical point of view.

The first chapter in al-Māwardi's book is devoted to the office of the imām, this term denoting the highest spiritual and political leader of the Islamic ummah. In other words the word is used in a sense that is practically identical with "caliph". He sets out by stating that the purpose of the imamate is to replace the prophet (i.e., as the leader of the ummah) "in the defence of faith and the administration of the world"-in this order. Thus the imamate (or, caliphate) is a necessary institution; opinions are divided only as to whether this necessity is based on reason alone or, in the last resort, on divine revelation. al-Māwardī decides for the latter alternative, for, he says rational thinking can lead to the conclusions that we should not wrong our neighbour and live with him in loyalty and justice, but it is the divine law (shari'ah) that entrusts the care for the best of the people to a ruler. The proof for this assertion is naturally sought in a passage from the Koran, namely 4: 62 "You who believe, obey God, and obey the Apostle

${ }^{1}$ R. A. Nicholson, Literary History of the Arabs, Cambridge 1930, p. $33^{8}$.

2 H. A. R. Gibb, "Al-Mawardi's Theory of the Caliphate", Gibb, Studies on the Civilization of Islam, 1962, p. 152. 
and those of you who are entitled to command". The use of reason, then, only implies a negative abstinence from wrong, the divine law inculcates positive care for the subjects. ('The argument is directed against the Mu'tazilites and the philosophers influenced by Greek thought.)

Then al-Māwardi proceeds to the question how a ruler is to be chosen. On principle, there must be an election; a hereditary office can be defended only in an indirect way (see below). But we are far from an election made by the people. al-Māwardi defines in three points the qualities of those who may participate in the choice: 'adãlah, or justice, capability of judging the requirements which a ruler should meet, and sound judgment. For the candidates of the imamate he sets up seven conditions: I. justice, 2. knowledge of tradition and capability of making decisions on points of law, 3 . good hearing, sight, and speech, 4. sound limbs, 5. judgment, 6. courage and determination to protect his country and fight the enemies, and 7. descendance from the Quraish.

Here, too, it is often possible to detect elements which are polemical against other opinions. The rule of election is directed against the $s h \bar{\imath}^{\prime} a h$, which claimed that the ruler could appoint his successor. The same is true of the requirement of belonging to the Quraish: here the $\operatorname{sh} \bar{\imath}$ 'ah required the caliph to be a descendant of Muhammad. al-Māwardī proves his thesis with the aid of a tradition from the "helpers" (ansār) of the Prophet: the Prophet is reported to have said: "The imamate belongs to the Quraish." A later writer, Ibn Khaldūn, adds a rational argument: it is important that a ruler belongs to a strong group animated by 'așabiyah, or the sense of belonging together.

Who are to elect the imam? al-Māwardī uses the term ahl al- 'aqd wa-l-hall "the people with power to bind and to loosen". In practice, this term denotes those who possess the necessary knowledge of the Koran and the Tradition to enable them to represent the ummah of Islam, in other words those who constitute the $i j m \bar{a}^{c}$, or consensus, of the Islamic community. Opinions are divided as to the minimum number of people who are to participate in the election. The idea that all those qualified should be present is rejected with reference to a precedent: when Abū Bakr was elected caliph, the congregation did not wait until all those absent had returned. The same event is used to prove that five electors are a sufficient number, while others claim that 
three, or even one, are enough; the last contention is based on the report that 'Abbās said to 'Alī, "Stretch out your hand in order that I may recognize you and the people may say that the Apostle's uncle has recognised his cousin". This prepares the way for another method of appointing a ruler, namely that the ruling prince himself nominates a successor.

al-Māwardi goes on to deal with the procedure of the election. The electors are to scrutinize the possible candidates and choose the one who best meets the requirements that can be placed on an imãm. When the choice has been made, it is final and cannot be invalidated if someone who is more qualified turns up. The election is then confirmed by a treaty between the elected one and his subjects. Only through this act, called bay'ah, investiture, oath of loyalty, is the elected one made the legitimate ruler.

If it happens that two imäms are elected in different parts of the country, this is not correct, "though some think that it is possible". Here we sense something of the realities of the political life of the time. Those who consider it possible argue that the two parts of the country are so distant from each other that the two rulers do not interfere with each other's functions. al-Māwardī insists that there can be only one $i m \bar{a} m$, thus also expressing his conviction that there can be only one Islamic state - one religion, one God, one state-an idea that is also present in the pair of opposite terms dōr al-islām-dār al-harb.

After some discussion of different pretendents to the throne, al-Māwardi proceeds to mention the caliph's right to appoint his successor. Strictly speaking, this would contradict the general principles, but there is a precedent that settles the case: Abū Bakr designated Omar as his successor. There follows a discussion of the possibility of designating a son or of designating two candidates to rule one after the other. A brief section develops the idea that every subject should know the caliph, i.e his name and his person, in other words know who he is. Furthermore, al-Māwardi remarks that the ruler should not be called khaliffatu-ll äh but rather khalïfatu rasülu$l l-M a \bar{a} h$, since only one who can be absent or die can have have a khaliffah, or substitute. As a matter of fact the title was actually used, at least by the Abbasids, perhaps as a result of Iranian influence.

Finally, al-Māwardĩ enumerates ten duties of the imam: 
I. to uphold religion according to the fixed principles-no innovations are allowed;

2. to administer justice and to be responsible that everyone receives his rights and no one is wronged;

3. to protect the area of Islam so that its inhabitants can earn their living and move freely;

4. to apply the rules of punishment so that God's prohibitions are observed;

5. to protect and fortify the borders;

6. to fight those who refuse to adopt Islam till they are converted or become tax-payers;

7. to collect fay' and alms;

8. to administer the affairs of the state without wastefulness or niggardliness;

9. to appoint officials; and

ro. to have the personal responsibility in all matters. Here is quoted Kor 38: 25 where Allah says, "O David, we have appointed you a viceroy in the earth; therefore judge between men justly, and do not follow caprice, lest it lead you astray from the way of God". And the prophet is quoted to have said, "Every one of you is a shepherd; everyone can be asked to render account of his flock".

Is there a myth of the state in Islam? The answer depends on the definition. There is no myth of origin telling us that "kingship came down from heaven", but there is a clear conviction that the state is religiously motivated. As an institution it is based on God's law as expressed in the Koran. It is part of Islam itself, which today is often regarded as an indefinable entity or principle that has been given to mankind through the revelation and which it is man's task to transform into concrete reality. It is this that gives Islamic political theory its flexibility, more unsophisticated in the earlier literature, which by the aid of the Koran, sunnah and $i j m \bar{a}^{c}$ tries to give theoretical motivations for status quo, more meditated in modernism, which seeks a way to "realizing Islam" within the framework of a modern society, partly even by means of a certain adaptation to Western technique and Western culture. Thus Islamic political theory is basically religious, and a distinction between religion and a secular state such as has been tried in 
108

HELMER RINGGREN

Turkey is strictly speaking abnormal from an Islamic point of view. The life of society is part of man's existence and cannot be withdrawn from God's control. The problem is to find in each time the right form for this divine control of society. 